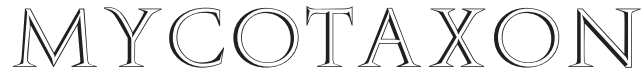

Volume 120, pp. 361-371

http://dx.doi.org/10.5248/120.361

April-June 2012

\title{
A new cystidiate variety of Omphalina pyxidata (Basidiomycota, tricholomatoid clade) from Italy
}

\section{Alfredo Vizzini ${ }^{1 \star}$, Mariano Curti $^{2}$, Marco Contu $^{3} \&$ Enrico Ercole $^{1}$}

${ }^{1}$ Dipartimento di Scienze della Vita e Biologia dei Sistemi - Università degli Studi di Torino

Viale Mattioli 25, I-10125, Torino, Italy

${ }^{2}$ Via Tito Nicolini 12, Pozzaglia Sabina, I-02030 Rieti, Italy

${ }^{3}$ Via Marmilla 12 (I Gioielli 2), I-07026 Olbia (OT), Italy

*CORRESPONDENCE TO: alfredo.vizzini@unito.it

Aвstract - A new variety of Omphalina pyxidata, var. cystidiata, is here described and illustrated based on morphological and molecular data. The new combination Infundibulicybe lateritia is introduced.

Key words - Agaricomycetes, Agaricales, omphalinoid fungi, Contumyces, taxonomy

\section{Introduction}

Within the omphalinoid fungi - small agarics with a convex to deeply umbilicate pileus, central stipe, thin context, decurrent lamellae, white sporeprint, and thin-walled inamyloid smooth spores (Norvell et al. 1994, Lutzoni 1997, Redhead et al. 2002a,b) - taxa with cystidiate basidiomata are thus far known only in the hymenochaetoid clade (Blasiphalia Redhead, Contumyces Redhead et al., Rickenella Raithelh.; Moncalvo et al. 2000, 2002, Redhead et al. 2002b, Larsson et al. 2006, Larsson 2007).

During fieldwork focused on bryophilous Galerina species, we collected an omphalinoid fungus growing on mosses close to Galerina discreta E. Horak et al. We initially believed that these specimens represented a new species of Contumyces (Contu 1997, Redhead et al. 2002b) based on the presence of well-differentiated pileo-, caulo-, cheilo-, and pleurocystidia and an irregular hymenophoral trama. However an ITS-rDNA analysis implied they might represent an unknown as-yet undescribed variety of Omphalina pyxidata (Bull.) Quél., the type species of Omphalina Quél. (Omphalina s.s. = tricholomatoid clade sensu Matheny et al. 2006, Binder et al. 2010 and Vizzini et al. 2011a). This genus is characterized by bryophilous basidiomata with a reddish brown tinged 
pileus and stipe, paler and well-developed lamellae, a smooth (not scaly) pileus, absence of hymenial and pileal cystidia, and presence of clamp-connections (Redhead et al. 2002a, Elborne 2008). We fully describe and illustrate the new taxon below.

\section{Materials \& methods}

\section{Morphology}

The macromorphological descriptions follow the detailed field notes taken on fresh material. The micromorphological descriptions are based both upon study of fresh and herbarium material. Dried material was revived in $5 \% \mathrm{KOH}$ and stained in Congo Red, Cotton Blue, and Melzer's reagent. The basidiospore range and means are based on measurements of 25 spores. In the macro- and microscopic descriptions $\mathrm{Q}=$ the quotient of spore length and width and $\mathrm{Qm}=$ the average quotient; $\mathrm{L}=$ number of entire lamellae; 1 = number of lamellulae between each pair of entire lamellae. The basidial width was measured at the broadest part, and the length was measured from the apex (sterigmata excluded) to the basal septum. Colour codes in brackets (e.g., Se 45) follow Séguy (1936), hereafter referred to as (Se). Author citations follow the IPNI Authors and the Index Fungorum Authors of Fungal Names websites. Herbarium abbreviations follow Thiers (2011) with the exception of "EM" and "GT", referring to the personal herbaria of Enzo Musumeci and Gérard Trichies, respectively. The type collection is housed at TO (Herbarium of the Department of Plant Biology, University of Turin, Italy), and both name and Latin diagnosis of the new variety as well as the new combination are deposited in MycoBank (http://www.mycobank.org).

\section{DNA extraction, PCR amplification, DNA sequencing}

Genomic DNA was isolated from $1 \mathrm{mg}$ of 3 herbarium specimens (TABLE 1) using the DNeasy Plant Mini Kit (Qiagen, Milan Italy). Universal primers ITS1f/ITS4 were used for the ITS region amplification (White et al. 1990; Gardes \& Bruns 1993). Amplification reactions were performed in PE9700 thermal cycler (Perkin-Elmer, Applied Biosystems) in a $25 \mu \mathrm{l}$ reaction mixture using the following final concentrations or total amounts: $5 \mathrm{ng}$ DNA, $1 \times$ PCR buffer $(20 \mathrm{mM}$ Tris/ $\mathrm{HCl} \mathrm{pH} 8.4,50 \mathrm{mM} \mathrm{KCl}), 1 \mu \mathrm{M}$ of each primer, $2.5 \mathrm{mM} \mathrm{MgCl} 2,0.25 \mathrm{mM}$ of each dNTP, 0.5 unit of Taq polymerase (Promega). The PCR program was as follows: $3 \mathrm{~min}$ at $95^{\circ} \mathrm{C}$ for 1 cycle; $30 \mathrm{~s}$ at $94^{\circ} \mathrm{C}, 45 \mathrm{~s}$ at $50^{\circ} \mathrm{C}$, $2 \mathrm{~min}$ at $72^{\circ} \mathrm{C}$ for 35 cycles, $10 \mathrm{~min}$ at $72^{\circ} \mathrm{C}$ for 1 cycle. PCR products were resolved on a $1.0 \%$ agarose gel and visualized by staining with ethidium bromide. PCR products were purified and sequenced by DiNAMYCODE srl (Turin, Italy). Sequence assembly and editing were performed using Geneious v5.3 (Drummond et al. 2010). The sequences are deposited in GenBank under the accession numbers given in TABLE 1.

\section{Sequence alignment and phylogenetic analysis}

Sequences included in the phylogenetic analyses were either generated in this study (TABLE 1) or retrieved from GenBank. Multiple sequence alignments for ITS fragments were generated using MAFFT (Katoh et al., 2002) with default conditions for gap opening and gap extension penalty. The alignment was slightly edited using MEGA 5.0 (Tamura et al. 2011). Phylogenetic analyses were performed using both Bayesian Inference (BI) 
TABLE 1. Omphalina pyxidata collections used in this study.

\begin{tabular}{l|l:l}
\hline Collections & Coll. NO., COUnTRY, DATE, COlLECTOR & ITS Acc. No. \\
\hline${ }^{*}$ O. pyxidata 1 & GT99398, France, 02/12/1999, G. Trichies & JQ671000 \\
\hdashline${ }^{*}$ O. pyxidata 2 & EM0434-05, Switzerland, 06/07/2005, E. Musumeci & JQ671001 \\
\hdashline O. pyxidata 3 & TO AV98, Italy, 10/10/2010, A. Vizzini & JN944402 \\
\hdashline O pyxidata 4 & Lamoure L66-118hl4, culture (see Lutzoni 1997) & OPU66450 \\
\hdashline${ }^{*}$ O. pyxidata var. cystidiata & TO HG2512, Italy, 11/11/2010, M. Curti & JQ671002 \\
\hline \hline
\end{tabular}

${ }^{*}=$ collections newly sequenced in this study.

and Maximum Likelihood (ML) approaches. The BI was performed with MrBayes 3.1.2 (Huelsenbeck \& Ronquist 2001) with four incrementally heated simultaneous Monte Carlo Markov Chains (MCMC) ran over 10 millions generations, under GTR $+\Gamma$ evolutionary model. Trees were sampled every 1000 generations resulting in an overall sampling of 10,001 trees; the first 2500 trees were discarded as "burn-in" (25\%). For the remaining trees, a majority rule consensus tree showing all compatible partitions was computed to obtain estimates for Bayesian Posterior Probabilities (BPP). Branch lengths were estimated as mean values over the sampled trees. ML was performed with RAxML (Stamatakis 2006) under GTRGAMMA model and using thorough bootstrap with 20 runs and 1000 replicates. In both analyses a Pseudoclitocybe cyathiformis sequence (Genbank HM191730) was used as outgroup taxon, according to Binder et al. (2010) and Vizzini et al. (2011a). The ML consensus tree was used merely for comparison with the Bayesian tree and to support the analysis. However the BPP (Bayesian posterior probability) over 0.75 and the ML bootstrap (MLB) over $50 \%$ values are reported in the resulting tree. Pairwise \% identity values of ITS sequences were calculated using MEGA 5.0 (Tamura et al. 2011).

\section{Results}

\section{Molecular results}

Bayesian and Maximum likelihood inferences were performed on a total of 18 samples, including 15 sequences available from GenBank and three newly sequenced specimens (TABLE 1). Final alignment length was $731 \mathrm{bp}$. Both Bayesian and Maximum likelihood analyses produced the same topology (FIG. 1). In both analyses our cystidiate collection clusters with four O.pyxidata sequences clearly forming a strongly supported clade (BPP 0.92 and MLB 85\%). The five O. pyxidata sequences show a pairwise \% identity value of 99.8 and could be considered conspecific.

The O.pyxidata sequence deposited in Genbank under the accession number JF908502 (MCVE 15669) was not used in the analysis because a Blastn search 


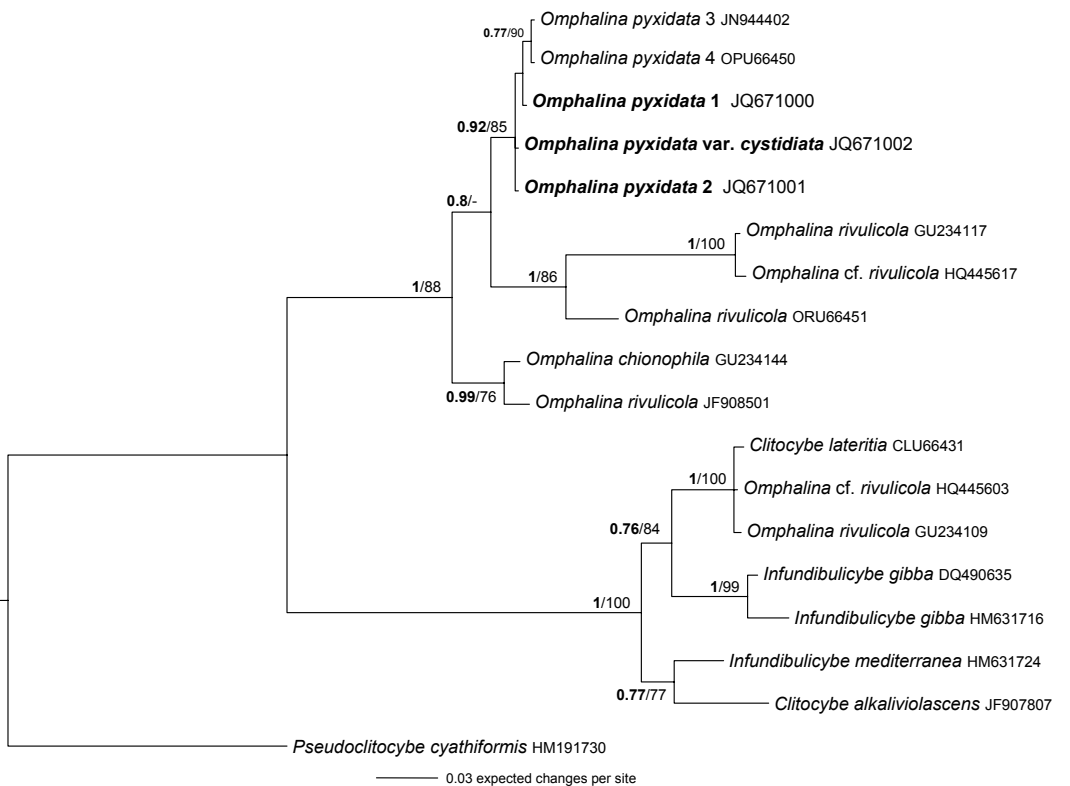

FIGURE 1. Bayesian phylogram obtained from the ITS sequence alignment. Support values for clades that are supported in either the Bayesian (Posterior Probabilities values - BPP) and Maximum likelihood (ML Bootstrap percentage - MLB) analyses are indicated. BPP above 0.75 and MLB above $50 \%$ are given above branches. Taxa in bold represent newly sequenced collections. Numbers (1-4) refer to the collections reported in TABLE I.

implies it represents a non-omphalinoid species in the Pluteus cinereofuscus/ P. nanus complex.

Clitocybe lateritia, together with two O. rivulicola (J. Favre) Lamoure collections, clearly falls within Infundibulicybe. Clitocybe alkaliviolascens Bellù clusters close to Infundibulicybe mediterranea Vizzini et al.

\section{Taxonomy}

Omphalina pyxidata var. cystidiata M. Curti, Contu \& Vizzini, var. nov. Figs 2-3 MycoBAnk MB564484

A varietate typica differt praesentia cystidiorum in lamella, pileo, et stipite. Habitat: graegatim, ad muscos.

Type - Italy, Latium, prov. Rieti, com. Pozzaglia Sabina, Valle del Turano, $42.1596^{\circ} \mathrm{N}$ $12.9652^{\circ} \mathrm{E}, 878 \mathrm{~m}, 11 . \mathrm{XI} .2010$, leg. M. Curti (TO HG2512 holotype).

EтумоLOGy - the specific epithet refers to the presence of hymenial as well as of pileoand caulocystidia. 


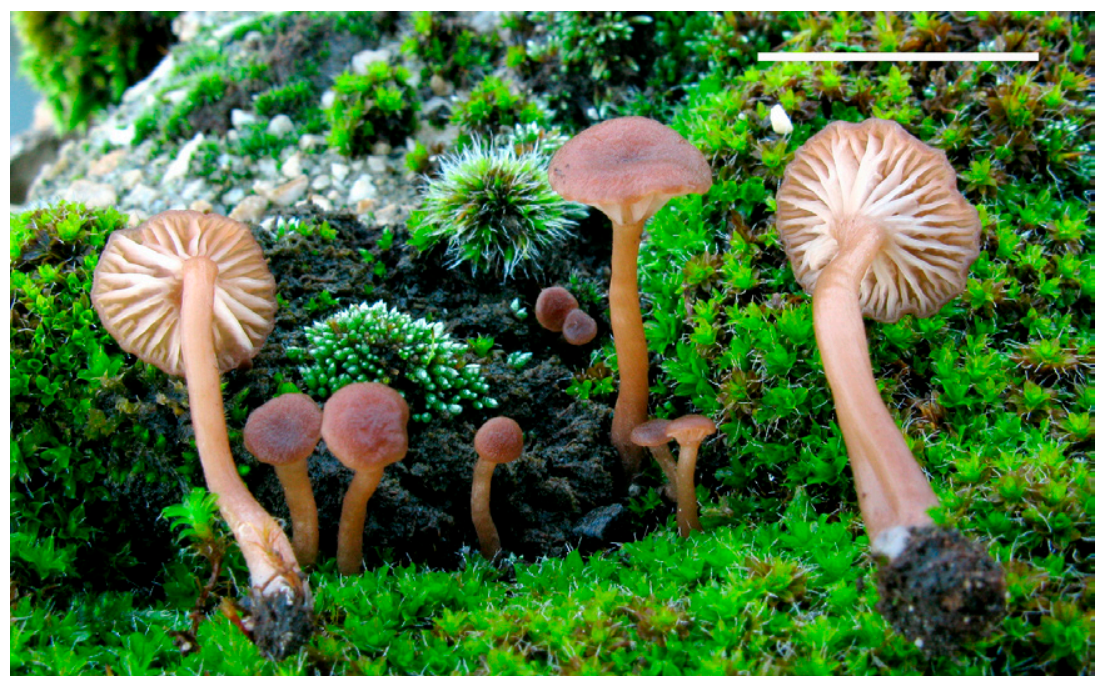

Figure 2. Omphalina pyxidata var. cystidiata. Basidiomata. Bar $=20 \mathrm{~mm}$.

Pileus 3-15 mm broad, at first convex to applanate, later with a slightly depressed centre, not or slightly hygrophanous, minutely pubescent, dark brown-fulvous (Se 96, 121, 126, 146, 251, 252) fading to light brown (Se 133, $134,173)$; margin at first involute then expanding, smooth to slightly striate in old basidiomes, whitish in dried basidiomes. LAmELLAE $(\mathrm{L}=18-25 ; 1=1-2)$ decurrent, thick, distant with lamellulae occasionally interspersed, strongly forked and intervenose, whitish to light ochre (Se 199-200), with entire concolorous edge. STIPE 15-40 × 1-3 mm, cylindrical, slightly broadened at the base, sinuous-flexuous, solid then fistulous, cartilaginous, paler than pileus, light ochre-brown (Se 133, 174, 203-204), minutely pruinose to subglabrous. Context elastic, thin, whitish-ochre to light ochre-brown $(\mathrm{Se} 133,134)$ in surface; smell and taste not distinctive. SPORE PRINT white.

Spores (7-)7.5-9(-10) × 4.5-6(-6.5) $\mu \mathrm{m}, \mathrm{Q}=1.3-1.7, \mathrm{Qm}=1.51$, largely ellipsoid to oblong in frontal view, lacrymoid to slightly amygdaliform in sideview, smooth, thin-walled, hyaline, inamyloid, mono-biguttulate, with a thick and evident hilum. BAsidia 28-46(-60) × 6-9 $\mu \mathrm{m}$, clavate, (two-) four-spored, sterigmata 3-7 $\mu \mathrm{m}$ long, usually clamped. Cheilocystidia $23-45 \times 3-6 \times$ 2.5-5 $\mu \mathrm{m}$, abundant, cylindrical, slender, apically tapered or slightly swollen, some laterally ventricose, hyaline, thin-walled, often with inner microguttules. Pleurocystidia 25-50 $(-65) \times 3.5-5.5 \times 2.5-5(-7) \mu \mathrm{m}$, similar to cheilocystidia, but slightly longer. HyMENOPHORAL TRAMA irregular, consisting of 3.3-7 $\mu \mathrm{m}$ wide hyphae. Pileipellis a cutis consisting of cylindrical, interwoven, 6-10 


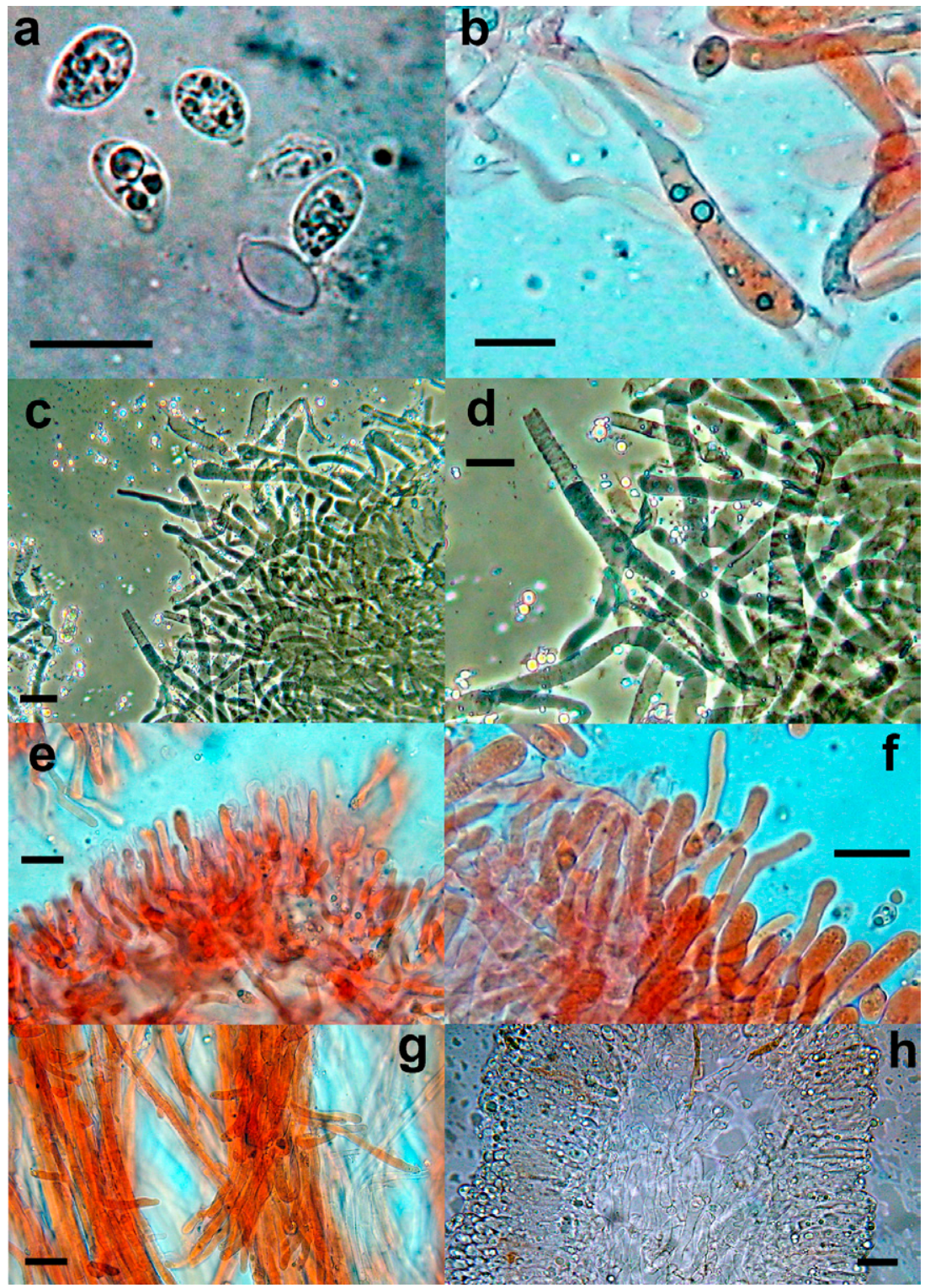

Figure 3. Omphalina pyxidata var. cystidiata. Microscopic features. a. Spores showing protruding hilum. b. Basidium with basal clamp. c. Pileipellis and pileocystidia. d. Encrusting pigment of pileipellis elements. e. Cheilocystidia (with inner microguttules). f. Pleurocystidia. g. Caulocystidia. h. Irregular hymenophoral trama. Bars: $\mathrm{a}-\mathrm{d}=10 \mu \mathrm{m} ; \mathrm{e}-\mathrm{h}=20 \mu \mathrm{m}$. 
$\mu \mathrm{m}$ wide hyphae; terminal elements with a subclavate $7-13 \mu \mathrm{m}$ wide apex; subcutis made up of 3-7 $\mu \mathrm{m}$ wide hyphae; PIGMENT epiparietal, minutely to strongly encrusting; PILEOCYSTIDIA numerous, fusiform to lageniform, 35-60 $\times 3.5-9 \times 3.5-5 \mu \mathrm{m}$. STIPITIPELLIS a cutis made up, in $5 \% \mathrm{KOH}$, of ochre-yellow 3-8 $\mu \mathrm{m}$ wide hyphae bearing minute incrustations; CAULOCYSTIDIA similar to hymenial cystidia $(30-65 \times 4-5 \times 3-5 \mu \mathrm{m})$. STIPITITRAMA non-sarcodimitic, consisting of hyphae up to $16 \mu \mathrm{m}$ wide. Clamp Connections present at all septa. Thromboplerous hyphae (= oleiferous hyphae sensu Clémençon 2004) present. Appressoria on host surface not observed.

НАвітAт - Gregarious, rarely subcaespitose, on Tortula muralis gametophytes (Bryophyta).

ADDITIONAL MATERIAL STUDIED - Omphalina pyxidata var. pyxidata: FRANCE, Lorraine, Moselle, Moyeuvre-Petite, 02 Dec 1999, on mosses, leg. G. Trichies (GT99398); SWITZERLAND, Canton Basel Stadt, Lange Erlen, 06 Jul 2005, on mosses, $250 \mathrm{~m}$ asl, leg. E. Musumeci (EM0434-05); ITALY, Piedmont, Chisone VAlley, Pinerolo, Prà Martino, 10 Oct 2010, on mosses, $1000 \mathrm{~m}$ asl, leg. A. Vizzini (TO AV98).

\section{Discussion}

As highlighted by Vizzini et al. (2011a), Omphalina s.s. is sister to Infundibulicybe Harmaja, a genus recently segregated from Clitocybe (Fr.) Staude (Harmaja 2003). In the six-gene region sequence analyses by Matheny \& al. (2006), Infundibulicybe falls outside the tricholomatoid clade, occupying an isolated position in the Agaricales (incertae sedis). However, recent analyses by Binder et al. (2010), Vizzini et al. (2011a) and Matheny (pers. comm.) place it with robust support as sister to the rest of the tricholomatoid clade. Omphalina and Infundibulicybe share the cream-reddish brown tinges of pileus and stipe, the long-decurrent lamellae, and strongly encrusting pigment (Harmaja 2003, Vizzini et al. 2011b).

Our molecular analysis (FIG. 1) and morphological comparison support the new taxon as a cystidiate variant of $O$. pyxidata thus far never described. Omphalina pyxidata var. cystidiata is unique within Omphalina s.s., where it is the only taxon thus far included that possesses well-developed cheilo-, pleuro, pileo-, and caulocystidia (Bigelow 1970, 1985, Singer 1970, Lamoure 1974, 1975 1982; Clémençon 1982, Bon 1997, Elborne 2008). Furthermore, we have found no cystidia in three examined European collections of O. pyxidata (see Additional MATERial STUdied). Morphologically, our new taxon resembles the omphalinoid bryophilous genera belonging to the hymenochaetoid clade (Redhead et al. 2002b, Antonín \& Noordeloos 2004). However, Rickenella differs in having a regular hymenophoral trama (Contu 1997, Redhead et al. 2002b) and Blasiphalia by growing specifically on the Blasia pusilla gametophyte (Marchantiophyta) and forming appressoria on host surface (Larsson et al. 
2006). Apart from molecular data that clearly support our new variety within the Agaricales, morphologically Contumyces (= Jacobia Contu, nom. illeg.; Hymenochaetales) might accommodate our taxon. Contumyces so far comprises only three species - C. rosellus (M.M. Moser) Redhead et al., C. vesuvianus (F. Brig.) Redhead et al., and C. brunneolilacinus (Contu et al.) Redhead et al. (Redhead et al. 2002b, Antonín \& Noordeloos 2004) - but only the first named has been sequenced. Contumyces rosellus differs from Omphalina pyxidata var. cystidiata by the pink to pale salmon-pink colouration, white stipe, and longer and larger cystidia. Contumyces vesuvianus has orange to fulvous basidiomata, larger basidiospores, rarer differently shaped (mucronate/rostrate) cystidia and intracellular pigment in the pileipellis hyphae. As originally described (Contu 1989), C. brunneolilacinus differs in having a lilaceous-brown, sharply tomentose, hygrophanous pileus, pink-lilac lamellae, a Pelargonium-like smell, lageno-capitate cystidia, and intracellular pigment in the pileipellis hyphae. Finally, C. brunneolilacinus sensu Antonín \& Noordeloos (2004) differs in having longer and larger cystidia and a non-tomentose pileal surface.

Our sequence analyses have also revealed that Clitocybe lateritia clusters in Infundibulicybe with two collections clearly misdetermined as O. rivulicola (FIG. 1). The three sequences are clearly conspecific (pairwise \% identity value $=99.7$ ). The two "O. rivulicola" sequences were derived from soil or ectomycorrhizal samples sampled from Dryas octopetala beds, as reported in two recent papers dealing with alpine-arctic fungi (Bjorbækmo et al. 2010, Geml et al. 2012). Clitocybe lateritia, a rare alpine-arctic species strictly associated with Dryas octopetala (Rosaceae), should be transferred to Infundibulicybe based on both sequence analyses and its Infundibulicybe-like features (reddish-brown colouration, strongly encrusting pigment in the pileipellis, partly lacrymoid spores) as inferred from Favre (1955), Gulden \& Jennsen (1988), and Bon (1997). Consequently, we propose the following new combination:

Infundibulicybe lateritia (J. Favre) Vizzini \& Contu, comb. nov.

MycoBank MB564485

$\equiv$ Clitocybe lateritia J. Favre, Ergebn. wiss. Unters. schweiz.

Natn. Parks, n.s. 5(33): 54, 199 (1955).

Type: Switzerland, Munt la Schera, 2400 m a.s.l., in Dryas beds, 21.08.1941, leg. J. Favre (Lectotype designated here, G-K16433; specimen illustrated in Favre 1955: Fig. 34; Pl. IV, Fig. 11).

Finally, Clitocybe alkaliviolascens, a species of the Infundibulicybe gibba complex recently described from Mediterranean areas and characterized by a dark brown pileus surface turning pink-violet with a $30 \% \mathrm{KOH}$ drop, and spores reaching $10 \mu \mathrm{m}$ in length (Bellù 1995, 1996), also belongs in Infundibulicybe. Bellù will propose the new combination in a forthcoming paper (Bellù, pers. comm.). 


\section{Acknowledgements}

Our most sincere thanks are due to Scott Redhead (Ottawa, Ontario, Canada), Lorelei Norvell (Portland, Oregon, USA), and Shaun Pennycook (Auckland, New Zealand) for their pre-submission reviews. We would like also to thank Luca Miserere (Torino, Italy) for identifying the moss species and Enzo Musumeci (Basel, Switzerland), Philippe Clerc (Chambésy, Switzerland) and Gérard Trichies (Neufchef, France) for sending herbarium specimens.

\section{Literature cited}

Antonín V, Noordeloos M. 2004. A monograph of Hemimycena, Delicatula, Fayodia, Gamundia, Myxomphalia, Resinomycena, Rickenella, and Xeromphalina (Tribus Mycenae sensu Singer, Mycena excluded) in Europe. IHW Verlag, Eching.

Bellù F. 1995. Die Trichterlinge (Clitocybe) der Sekt. Infundibuliformes Fr. und ihre Reaktion gegenüber Kalilauge. Sydowia Beih. 10: 28-34.

Bellù F. 1996. Alcune specie mediterranee di recente identificazione con particolare riguardo al genere Clitocybe. Riv. Micol. 39: 99-114.

Bigelow HE. 1970. Omphalina in North America. Mycologia 62: 1-32.

http://dx.doi.org/10.2307/3757709

Bigelow HE. 1985. North American species of Clitocybe. Part II. Beih. Nova Hedwigia 81: 281-471.

Binder M, Larsson K.-H, Matheny PB, Hibbett DS. 2010. Amylocorticiales ord. nov. and Jaapiales ord. nov.: early diverging clades of Agaricomycetidae were dominated by corticioid forms. Mycologia 102: 865-880. http://dx.doi.org/10.3852/09-288

Bjorbækmo MFM, Carlsen T, Brysting A, Vrålstad T, Høiland H, Ugland KI, Geml J, Schumacher T, Kauserud H. 2010. High diversity of root associated fungi in both alpine and arctic Dryas octopetala. BMC Plant Biol. 2010, 10: 244. http://dx.doi.org/10.1186/1471-2229-10-244

Bon M. 1997. Flore mycologique d'Europe 4. Les Clitocybes, Omphales et ressemblants. Doc. Mycol., Mém. Hors-Sér. 4: 1-181.

Clémençon H. 1982. Kompendium der Blätterpilze Europäische omphalinoide Tricholomataceae. Zeitschr. F. Mykol. 48: 195-237.

Clémençon H. 2004. Cytology and plectology of the Hymenomycetes. Bibl. Mycol. 199: 1-488.

Contu M. 1989. Rickenella brunneolilacina sp. nov. con note sul genere Rickenella in Sardegna. Micol. Veget. Medit. 4: 57-62.

Contu M. 1997. Jacobia, un nuovo genere di Tricholomataceae omfalinoidi. Boll. Gruppo Micol. G. Bres. (n.s.) 40(2-3): 169-713.

Drummond AJ, Ashton B, Buxton S, Cheung M, Cooper A, Duran C, Field M, Heled J, Kearse M, Markowitz S, Moir R, Stones-Havas S, Sturrock S, Thierer T, Wilson A. 2010. Geneious v5.3. Available from http://www.geneious.com/.

Elborne SA. 2008. Omphalina Quél. 235-237, in: H Knudsen, J Vesterhold (eds). Funga Nordica - Agaricoid, boletoid and cyphelloid genera. Nordsvamp, Copenhagen.

Favre J. 1955. Les champignons supérieurs de la zone alpine du Parc national Suisse. Ergebn. wiss. Unters. schweiz. Natn. Parks, n.s. 5(33): 1-212.

Gardes M, Bruns TD. 1993. ITS primers with enhanced specificity for basidiomycetes - application to the identification of mycorrhizae and rusts. Mol. Ecol. 2: 113-118.

http://dx.doi.org/10.1111/j.1365-294X.1993.tb00005.x 
Geml G, Timling I, Robinson CH, Lennon N, Nusbaum HC, Brochmann C, Noordeloos ME, Taylor DL. 2012. An arctic community of symbiotic fungi assembled by long-distance dispersers: phylogenetic diversity of ectomycorrhizal basidiomycetes in Svalbard based on soil and sporocarp DNA. J. Biogeogr. 39: 74-88. http://dx.doi.org/10.1111/j.1365-2699.2011.02588.x

Gulden G, Jenssen KM. 1988. Arctic and alpine fungi, 2. Soopkonsulenten, Oslo.

Harmaja H. 2003. Notes on Clitocybe s. lato (Agaricales). Ann. Bot. Fennici 40: 213-218.

Huelsenbeck JP, Ronquist F. 2001. MrBayes: Bayesian inference of phylogeny. Bioinformatics 17: 754-755. http://dx.doi.org/10.1093/bioinformatics/17.8.754

Katoh K, Misawa K, Kuma K, Miyata T. 2002. MAFFT: a novel method for rapid multiple sequence alignment based on fast Fourier transform. Nucl. Acids Res. 30: 3059-3066. http://dx.doi.org/10.1093/nar/gkf436

Lamoure D. 1974. Agaricales de la zone alpine. Genre Omphalina (1ère partie). Trav. Sci. Parc Natl. Vanoise 5: 149-164.

Lamoure D. 1975. Agaricales de la zone alpine. Genre Omphalina (2e partie). Trav. Sci. Parc Natl. Vanoise 6: 153-166.

Lamoure D. 1982. Alpine and circumpolar Omphalina species. 201-215, in: GA Laursen, JF Ammirati (eds). Arctic and Alpine Mycology 1. University of Washington Press, Seattle.

Larsson K-H. 2007. Re-thinking the classification of corticioid fungi. Mycol. Res. 111: 1040-1063. http://dx.doi.org/10.1016/j.mycres.2007.08.001

Larsson K-H, Parmasto E, Fischer M, Langer E, Nakasone KK, Redhead SA, 2006. Hymenochaetales: a molecular phylogeny for the hymenochaetoid clade. Mycologia 98: 926-936. http://dx.doi.org/10.3852/mycologia.98.6.926

Lutzoni F, 1997. Phylogeny of lichen- and non-lichen-forming omphalinoid mushrooms and the utility of testing for combinability among multiple datasets. Syst. Biol. 46: 373-406. http://dx.doi.org/10.1093/sysbio/46.3.373

Matheny PM, Curtis JM, Hofstetter V, Aime MC, Moncalvo J-M, Ge Z-W, Yang Z-L, Slot JC, Ammirati JF, Baroni TJ, Bougher NL, Hughes KW, Lodge DJ, Kerrigan RW, Seidl MT, Aanen DK, DeNitis M, Daniele GM, Desjardin DE, Kropp BR, Norvell LL, Parker A, Vellinga EC, Vilgalys R, Hibbett DS. Mycologia 98: 982-995. http://dx.doi.org/10.3852/mycologia.98.6.982

Moncalvo J-M, Lutzoni F, Rehner SA, Johnson J, Vilgalys R. 2000. Phylogenetic relationships of agaric fungi based on nuclear large subunit ribosomal DNA sequences. Syst. Biol. 49: 278-305. http://dx.doi.org/10.1093/sysbio/49.2.278

Moncalvo J-M, Vilgalys R, Redhead SA, Johnson JE, James TY, Aime MC, Hofstetter V, Verduin AJW, Larsson E, Baroni TJ, Thorn RG, Jacobsson S, Clémençon H, Miller OK. 2002. One hundred and seventeen clades of euagarics. Mol. Phylog. Evol. 23: 357-400. http://dx.doi.org/10.1016/S1055-7903(02)00027-1

Norvell LL, Redhead SA, Ammirati JF. 1994. Omphalina sensu lato in North America 1-2. 1: Omphalina wynniae and the genus Chrysomphalina. 2: Omphalina sensu Bigelow. Mycotaxon 50: 379-407.

Redhead SA, Lutzoni F, Moncalvo JM, Vilgalys R, 2002a. Phylogeny of agarics: partial systematics solutions for core omphalinoid genera in the Agaricales (Euagarics). Mycotaxon 83: 19-57.

Redhead SA, Moncalvo J-M, Vilgalys R, Lutzoni F, 2002b. Phylogeny of agarics: partial systematics solutions for bryophilous omphalinoid agarics outside of the Agaricales. Mycotaxon 82: 151-168.

Séguy E. 1936. Code universel des couleurs. Paul Chevalier, ed. Paris.

Singer R. 1970. Omphalinae (Clitocybeae-Tricholomataceae Basidiomycetes). Flora Neotropica 3: 1-84. 
Stamatakis A. 2006. RAxML-VI-HPC: Maximum Likelihood-based phylogenetic analyses with thousands of taxa and mixed models. Bioinformatics 22: 2688-2690.

http://dx.doi.org/10.1093/bioinformatics/btl446

Tamura K, Peterson D, Peterson N, Stecher G, Nei M, Kumar S. 2011. MEGA5: Molecular Evolutionary Genetics Analysis using Maximum Likelihood, Evolutionary Distance, and Maximum Parsimony Methods. Mol. Biol. Evol. 28(10): 2731-2739. http://dx.doi.org/10.1093/molbev/msr121

Thiers B. 2011. [continuously updated] Index Herbariorum: A global directory of public herbaria and associated staff. New York Botanical Garden's Virtual Herbarium. http://sweetgum.nybg.org/ih/

Vizzini A, Contu M, Ercole E. 2011a. Musumecia gen. nov. in the tricholomatoid clade (Basidiomycota, Agaricales) related to Pseudoclitocybe. Nord. J. Bot. 29(6): 734-740. http://dx.doi.org/10.1111/j.1756-1051.2011.01169.x

Vizzini A, Contu M, Musumeci E, Ercole E. 2011b. A new taxon in the Infundibulicybe gibba complex (Basidiomycota, Agaricales, Tricholomataceae) from Sardinia (Italy). Mycologia 103: 203-208. http://dx.doi.org/10.3852/10-137

White TJ, Bruns TD, Lee S, Taylor J. 1990. Amplification and direct sequencing of fungal ribosomal RNA genes for phylogenetics. 315-322, in: MA Innis et al. (eds). PCR Protocols. Academic Press, London. 